Winter 2014

\title{
The King's Coral Body: A Natural History of Coral and the Post- Tragic Ecology of The Tempest
}

Shannon Kelley

Fairfield University, skelley@fairfield.edu

Follow this and additional works at: https://digitalcommons.fairfield.edu/english-facultypubs Copyright 2014 University of Pennsylvania Press

All rights reserved. Archived here with a 12 month embargo at the request of the copyright holder.

\section{Peer Reviewed}

\section{Repository Citation}

Kelley, Shannon, "The King's Coral Body: A Natural History of Coral and the Post-Tragic Ecology of The Tempest" (2014). English Faculty Publications. 69.

https://digitalcommons.fairfield.edu/english-facultypubs/69

\section{Published Citation}

Shannon Kelley. "The King's Coral Body: A Natural History of Coral and the Post-Tragic Ecology of The Tempest." Journal for Early Modern Cultural Studies 14.1 (2014): 115-142.

This item has been accepted for inclusion in DigitalCommons@Fairfield by an authorized administrator of DigitalCommons@Fairfield. It is brought to you by DigitalCommons@Fairfield with permission from the rightsholder(s) and is protected by copyright and/or related rights. You are free to use this item in any way that is permitted by the copyright and related rights legislation that applies to your use. For other uses, you need to obtain permission from the rights-holder(s) directly, unless additional rights are indicated by a Creative Commons license in the record and/or on the work itself. For more information, please contact digitalcommons@fairfield.edu. 


\title{
The King's Coral Body:
}

A Natural History of Coral and the Post-Tragic Ecology of The Tempest

\author{
SHANNON KELLEY
}

A B S T R A C T

This essay presents a natural history of coral, an animal that was once thought to be a plant that transformed into stone upon exposure to air. According to Ovid, Perseus propagated the first coral when be rested the Medusa's severed head on a bed of freshly barvested seaweed. When the seaweed petrified, nymphs gathered its seeds and filled the ocean with forests of coral (gorgonia). According to the lyrics of Ariel's second song ("of his bones are coral made") in The Tempest, Alonso's corpse offers this stunning alternative to decay: a wondrous constancy whose ontological status is unclear. After considering coral's taxonomic indeterminacy in Aristotle, Pliny, and Linnaeus, this essay historicizes coral in a wide variety of Renaissance contexts, including lapidaries, the global trade of Mediterranean coral to southern India, portraits of Christ as a child, and the garden sea grotto. Drawing upon these various contexts, the essay argues that King Alonso survives the post-tragic ecology of The Tempest due to a debumanizing, yet elevating bond with coral.

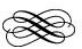

Tn Ariel's second song from The Tempest, "Full fathom five thy father lies; / 1 Of his bones are coral made," King Alonso's drowned corpse avoids physical decay when its eyes become pearls and its bones petrify into coral; but how, exactly, was coral understood?' How did early modern authors describe its origins or define its essence? If it began as a mere underwater plant (herb, shrub, grass, or tree), its mineralized form was curative, perpetual, and exceedingly valuable. Alonso's second, coral body, then, was a significant improvement on his pre-tempest mortality.

Although we have seen a dramatic increase in the number of ecocritical readings that consider the nonhuman, scholars have just begun to recognize

THE JOURNAL FOR EARLY MODERN CULTURAL STUDIES

VOL. 14, NO. 1 (WINTER 2014) (C) 2014 
the full importance of the diverse range of beasts, flora, and fauna in Shakespearean texts. ${ }^{2}$ To appreciate Alonso's spiritual transformation in The Tempest (c. 1610), it helps to understand coral's legacy and function in early modernity, particularly as it pertains to the generic specificities of the romance. Shakespeare's last plays attend to the consequences of past tragic action, and, as Sarah Beckwith emphasizes, these plays explore the circumstances under which "forgiving holds out the possibility of redemption from the predicament of irreversibility" (2). Coral, which reverses its own death, is the ideal nonhuman presence in the post-tragic theater of resurrection. Simultaneously animal, vegetable, and mineral, coral not only challenges a traditional human and nonhuman division that privileges human exceptionality and endurance, it also occupies an alternate temporality through its wondrous resistance to biological decay.

The first section of this essay historicizes the Ovidian roots and controversial taxonomy of coral, which most natural philosophers assumed to be a brilliant, vermillion-colored sea shrub or branching tree that transforms into a precious stone upon exposure to air. I examine a wide range of cultural artifacts, including lapidaries, the economic details of the global trade in Mediterranean coral to southern India, and portraits of the Madonna with Christ as a child, to demonstrate that coral was highly valued for its apotropaic powers and consistently associated with resurrection. In the second section, I locate coral's artificial habitat among the collection of seashells, stalactites, fossil, amber, and pearl found in the early modern sea grotto, and by doing so I am able to show that Shakespeare may have been influenced by Samuel Daniel's investiture masque Tethys, Queen of Nymphs and Rivers (1610) and the early Stuart vogue for Italianate gardens. In the third section, I explore three ways in which Alonso's dehumanizing bond with coral both shelters and elevates him. The untruth in Ariel's song - that Alonso has drowned - does not simply initiate Ferdinand's mourning or demonstrate that poetry makes death beautiful: the directive in act $\mathrm{I}$ is to read the play as a series of losses that can only be recovered by attending to a past that does not decompose-such are the conditions for the possibility of repentance, forgiveness, acknowledgement, restitution, and justice.

\section{A Natural History of Coral}

The classic Linnaean taxonomy begins by asking an essentialist question: "Is it animal, vegetable, or mineral?" Still, exceptions existed even for Linnaeus, 
whose Systema Naturae retains a category for "zoophytes," or "plant-animals," among which coral figures prominently:

zoopHYTA are composite animals, holding a medium between animals and vegetables. Most of them take root and grow up into stems; multiplying life in their branches and deciduous buds, and in the transformation of their animated blossoms or polypes which are endowed with spontaneous motion. Plants therefore resemble Zoophytes, but are destitute of animation and the power of locomotion: and Zoophytes are as it were plants, but furnished with sensation and the organs of spontaneous motion. (4.4)

Corals occupy an impossible position in Linnaean taxonomy: they are composite animals, but they possess the roots, branches, deciduous buds, and blossoms of plants. To Linnaeus, coral's post-Cartesian animality descends from its capacity for sensation and spontaneous motion, but the species was still best described as "holding a medium" between two kingdoms (4.4). Linnaeus, then, does not depart from the way Greco-Roman naturalists categorized coral. In de Partibus Animalium, Aristotle explains that certain marine creatures (the sea sponge, ascidian or "sea squirt," star fish, sea urchin) share animal and plant characteristics because "nature passes from lifeless objects to animals in such unbroken sequence, interposing between them beings which live and yet are not animals, that scarcely any difference seems to exist between two neighbouring groups owing to their close proximity" (I04). Because coral is a bloodless animal (like the sea sponge) that lacks locomotion or perception, Aristotle concludes that coral is inferior to other species in the animal kingdom, although superior to many marine plants. Pliny describes coral in his Naturalis Historia under his explanation of natural remedies, forty-three of which origi-

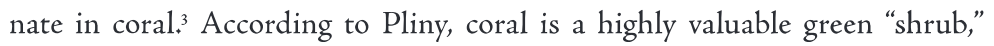
whose white berries are "soft while under water, but the moment they are removed from it, they become hard and red" (32: II). With this assertion, Pliny departs from the Greek naturalist Theophrastus's position, since Theophrastus specifically categorizes coral as a vegetal mineral, "like a stone ... red in color and rounded like a root" that "grows in the sea" (55). Eighteenth-century naturalists were still flummoxed, but less likely to identify coral as a mineral; in 1786 John Ellis suggested that coral was "an animal growing in the form of a plant," and that it might be the missing link "that unites the animal and vegetable kingdoms of Nature" (I08). 
Scientific consensus today shadows Alonso's corpse, as coral is defined by a skeletal component rather than Linnaean taxonomy: according to the Oxford English Dictionary, coral is now considered the "continuous skeleton secreted by many tribes of marine coelenterate polyps for their support and habitation" (def. n.I). Writing in 20or, naturalist Eric H. Borneman admits that "the old arguments about whether corals were animal, vegetable, or mineral were all partly correct ... corals, as an animal group, can be considered as having two distinct parts ... a living component and a skeletal component" (38). Coral reefs still grow "plant-like," but this growth ironically consists of accumulated, calcereous skeletal deposits of marine invertebrates, suggesting that coral (and amber, pearl, or coal) still possesses a unique, equivocal biogenic ontology. Alive in death, these entities readily prove Ovid's assertion that "all things change, but nothing, sure, doth perish" (15: 183$).^{4}$

Although the authors of medieval lapidaries praised coral's sovereign virtues, they could not define its essence. For example, the naturalist Bartholomew de Glanville writes "corall is gendred in the red see and is a tree aslonge as it is coueryd with water, but anone as it is drawen out it torneth in to stone" (XVI: xxxiii, 563). Although minerals do not have souls (anima), Albertus Magnus records the common belief that certain stones retained apotropaic properties unique to their substantial forms "imparted by the powers of heaven" (25). According to these terms, to possess coral would be to possess the properties of a pharmacopeia. In his key medieval lapidary, de Mineralibus, Albertus argues that coral is a stone "taken from the sea ... shaped like the twigs of plants," that relieves "any sort of bleeding," epilepsy, menstruation, and protects against "storms, lightning, and hail" (8I). The late-sixteenth-century Sloane Lapidary, a translation of a pre-1243 Anglo-Norman Prose Lapidary, describes how coral "waxeth in the sea as a grass" but "when it is out of ye sea it is red and lyke a branch" that "defendeth and kepeth a man from lightning, thunder, and from tempest of wether" (English Medieval Lapidaries 125). The late-fifteenth-century North Midland Lapidary demonstrates how coral grows from sea foam, air, and dew: "corayle is a ston yt is mad of ye fom of ye se and ye dew; and ye wynd beres it upe in-to ye eyr, \& yer it sal congele \& wax hard $\&$ be-comes a ston" (53). According to the late-fifteenth-century Peterborough Lapidary, "coral is a ston that growth in the red see as an erbe that is gren, $\&$ when it is owte in the eyr it wexyth hard $\&$ red $\&$ recembleth to a branche" (77). According to the Peterborough manuscript, coral alleviates pain, stanches blood, brings romantic love, multiplies the fruit of vineyards, gardens or fields, 
and subdues both tempests and "whirlewyndes." Its mixed nature allows it to protect gardens on earth from the disorder of the elements (deluge, tornados, and storms) and to thrive, unharmed, in land or sea, protecting human bodies and plants.

Most of us are familiar with the conventional evocation of "coral lips" and golden hair in the blazons composed by lyric poets, but scholars have recently uncovered England's influential role in the global trade in coral..$^{5}$ In a 2009 study, historian Francesca Trivellato argues that the importance of coral for the Mediterranean economy has been "largely forgotten" (224) because the rich coral reefs along the African coastline were depleted by the mid-eighteenth century. In the sixteenth and seventeenth centuries, however, coral was harvested off the coasts of Algeria and Tunis, although some could be found in European regions: Liguria, Sardinia, Corsica, Sicily, Calabria, and the shorelines of Provence and Tuscany. Trivellato describes the coral fishing process:

Every year, from April to September, hundreds of fishermen from the poorest coastal villages in the regions of Naples and Genoa and from the islands of Corsica and Sardinia went to sea. The technology that they used for coral fishing was virtually the same as in antiquity. Each boat carried a wooden cross to which nets were attached. When approaching a coral reef, the fishermen lowered the cross to the bottom of the sea; when it ran aground on a reef, they moved the boat in all directions to uproot the coral branches that were caught in the nets. More often than not one of them had to dive to adjust the net. Each boat normally carried seven men, working as oarsmen and fishermen. [Jean-Baptiste] Tavernier speaks of two hundred boats leaving from the coast of Genoa. (227)

The season ended in November, and manufacturing centers in Livorno and Marseilles processed and sold the harvest. Giovanni Pivati's sketch of coral fishing (fig. I) accurately depicts the process while reflecting taxonomic plurality: coral branches resemble roots of a tree without a stem in the top image and branches that grow from an underwater rock in the bottom.

In Jacopo Zucchi's imaginative rendering of coral fishing, The Treasures of the Sea (Coral Fishers), also known as The Discovery of America (c. 1560), men harvest coral and dive for pearls in the painting's background, while sea nymphs pose on an archipelago in the foreground (fig. 2). Coral-raw or processedand other riches of the sea dominate the painting, which is a vibrant, baroque 


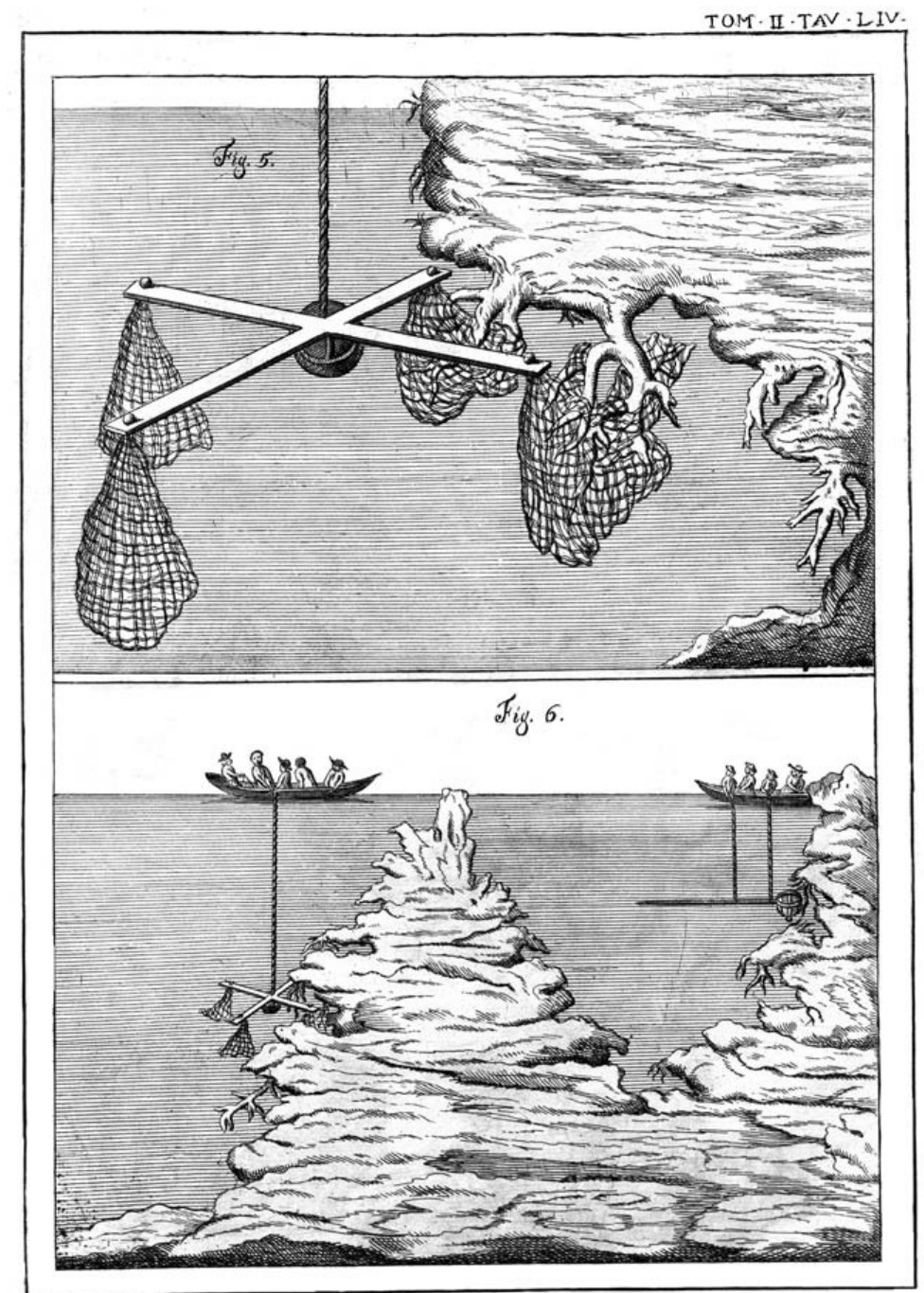

Fig. I: Fishing for coral in the eighteenth century. Giovanni Francesco Pivati, Nuovo dizionario scientifico e curioso sacroprofano. (Venice: Milocco, 1746-5I), vol. 2, table 54. Department of Special Collections, Memorial Library, University of Wisconsin-Madison. 


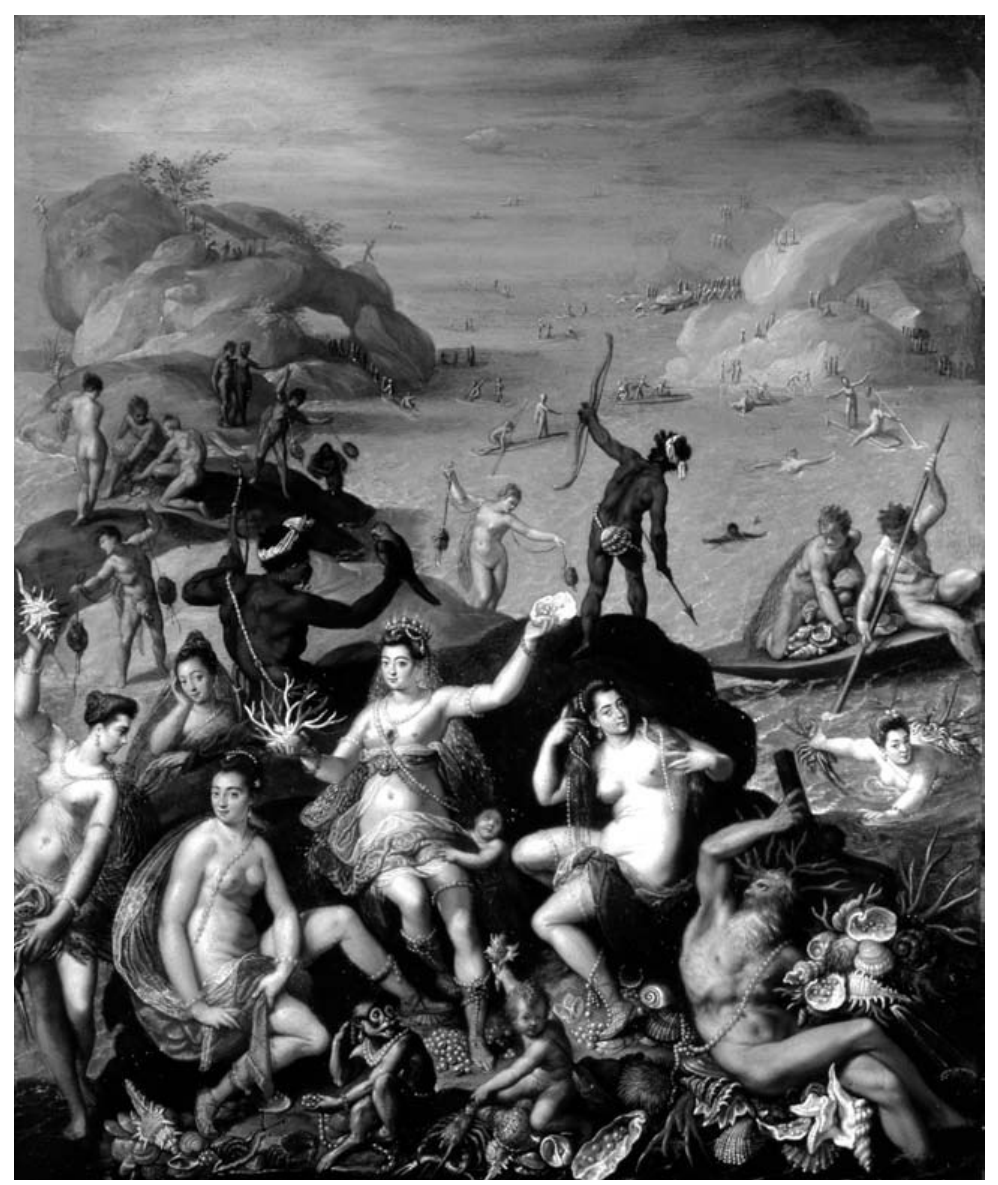

Fig. 2: "The Treasures of the Sea (Coral Fishers)" (c. 1560). Jacopo Zucchi (154I-90). Rome: Galleria Borghese.

harvest scene. The figures in the foreground replicate coral's branching shape, as the island chain appears to open into a cornucopia from which spill lobsters, oysters, snails, conch, sea shells, pearl and coral jewelry, and a monkey decked with pearls. In her cultural history of gemstones and jewelry, art historian Marcia Pointon observes that while pearl connotes "exterior, impenetrable beauty," coral's vermillion branches, by contrast, "invoke the interior of the body with its arteries" (108). This opposition between red and white is offset by the turbaned, black males who carry coral bows and arrows. The presence of 
hunters in an angling painting is puzzling, as is Zucchi's decision to position a parrot, suggestive of a Caribbean falcon, directly above the white body of a crowned sea nymph. The painting is an invitation to master multiple dominions through global trade, slave or indigenous labor, and the conquest of nature, but it also reinforces coral's taxonomic plurality: in its capacity as an underwater animal, it is hunted with traps, nets, and poles; in its capacity as an herb, grass, or tree, it replaces the wheat and fruit of a still-life cornucopia; and in its lithophyte capacity, Zucchi depicts coral beads strung near other precious stones.

In his overview of Anglo-Indian trade between I60I and 1757, Bal Krishna notes that the East India Company (which received its royal charter in I60I) sold coral and ivory from Africa to southern India, eventually at an immense profit as the English and Dutch monopolized the coral trade through a combination of outright piracy and official economic policy. By 1616, coral was one of England's three main commodities exported to India, and in 1639 coral was, after broadcloth, "the most staple and vendible commodity that Europe produced" (Krishna II4). It was so profitable that the English even traded coral for diamonds. Gedelia Yogev, in her history of the eighteenth-century diamond trade, observes that "after the early sixteenth century diamonds were the main item in jewelry imports from India, and coral took first place in exports to the East, for a long time being an essential commodity in all trade with India" (I03). Pliny had considered India's desire for coral to be evidence of the contingency of value:

In the same degree that people in our part of the world set a value upon the pearls of India- a subject on which we have already spoken on the appropriate occasion at sufficient length-do the people of India prize coral: it being the prevailing taste in each nation respectively that constitutes the value of things. (32: II)

After listing coral's use as a remedy for a variety of illnesses, Pliny recalls that "before it was known in what estimation coral was held by the people of India, the Gauls were in the habit of adorning their swords, shields, and helmets with it" (32: II).

Mediterranean coral was used for funerary purposes in cremation ceremonies across southern India's Deccan Plateau. In 1613, William Biddulph wrote to the company from Surat: "coral ... [is] a chief commodity here ... being a 
custom in Decanie ... for to buy as much of it as they can, and hoard it up as it were gold, and the more they have of it in their house the greater honour it is for them, and when they die they burn it all with them" (qtd. in Yogev 103). In Southeast Asia, Europe, and North Africa, coral occupies a liminal space between death and resurrection. But other sea creatures did as well. The scallop, the badge of pilgrims of St. James, assumed a sacred dimension when its shell was placed on gravesites to assist the deceased's passage to the afterlife. Athanasius Kircher affirms popular beliefs in support of nature's renewal and its ability to arrest death by claiming that, on the coast of Sicily, "the shells of shell-fish, after being ground to powder, come to life again and start reproducing, if this powder is sprinkled with water" (qtd. in Bachelard I15). Belief that providence instructed nature led Thomas of Cantimpré to claim that coral "terrifies demons" since its branches "frequently form a cross."

Because of coral's shape, color, and resistance to decay, European artists used it to allegorize Christ's passion. In one example, a coral branch is suspended over the Virgin's throne (Andrea Mantegna's Madonna della Vittoria, 1495), and in another example a branch is draped in a necklace around the infant Christ (Follower of Hugo van der Goes, Virgin and Child, c.1500) to recall the crucifixion and resurrection. These Christian appropriations contrast with coral's mythic origins in Ovid's Metamorphoses, which describe how Perseus, after freeing Andromeda, propagated the first coral when he rested the $\mathrm{Me}$ dusa's severed head on a bed of freshly harvested seaweed. When the seaweed transmogrified to coral, nymphs, observing the change with delight, gathered its seeds and filled the ocean with forests of incorruptible plants:

[Perseus] spread

Soft leaves and certain tender twigs that in the water grew

And laid Medusa's head thereon. The twigs, yet being new

And quick and full of juicy pith, full lightly to them drew

The nature of this monstrous head; for both the leaf and bough

Full strangely at the touch thereof became both hard and tough.

The sea nymphs tried this wondrous fact in divers other rods

And were full glad to see the change, because there was no odds

Of leaves or twigs or of the seeds new shaken from the cods.

For still like nature ever since is in our coral found

That, look how soon it toucheth air, it waxeth hard and sound.

And that which under water was a stick, above is stone. (4.908-20) 
In Ovid's account, coral absorbs its power from female sources-the Medusa's destructive gaze (in some versions, the gorgon's blood touches the plants), Andromeda's virginity, and the erotic sea nymphs who colonize the searather than Christian sacrifice. Because it is monstrous in origin and gifted with the capacity to "self-propagate in perpetuity," David Williams argues that coral is the most heterogenous of all the "creatures of the mineral realm:" it is a "a totalising monster, it is mineral in that its consistency is adamantine, vegetal in that it is tendrilous and alive but stationary, and animal in that it is carnivorous" (215).

It could be seen as a surprise that-despite its unruly taxonomy and origin in the Medusa's petrifying gaze-coral was said to generate immense security: it allegedly protects life, heals wounds, creates good endings, and renders bonds eternal. Because pre-modern descriptions of coral consistently celebrate its apotropaic qualities, the references to coral in Ariel's song reinforce some of the central properties of Shakespearean romance: miracles, healing, and wondrous reunion. But there are other reasons that coral's natural history reinforces the generic patterns of the post-tragic plays, including its association with resurrection, evident in a close reading of Ariel's song. According to Steve Mentz, the play needs the song for two reasons: one is for the narrative, to move Ferdinand toward Miranda and a heterocomic resolution, and the other is metaphorical, to "represent the transforming powers of oceanic magic." Still, Mentz puzzles over its "terrifying ... glittering but false vision of submerged treasure" (7-8), a treasure that we never find. But what if the song signaled the presence of Christ to an early modern audience? It undoubtedly comforted Ferdinand, whose fury and passions were calmed also by the music and by the evoked memory of his "drowned father" (I.2.406). Given coral's natural history, it is possible to argue that the song was less terrifying and more apotropaic, or in the sense that it shares properties with religious iconography, that its imagery was both dreadful and welcoming. Pointon's work is crucial to this claim; she has observed "countless examples from the Quatrocentro of the Christ Child wearing coral" (368). Alonso might be alone, lost, or dead in a space of imprisonment and judgment, but the song's reference to coral suggests resurrection. This resurrection motif is also present when Ferdinand immediately thinks of heaven-declaring "this is no mortal business" (I.2.407) - after he hears Ariel's song, ostensibly experiencing a moment of grace.

The song's third line mentions the pearl, a product of a marine animal with mythological and religious associations: 
Full fathom five thy father lies,

Of his bones are coral made;

Those are pearls that were his eyes;

Nothing of him that doth fade,

But doth suffer a sea-change

Into something rich and strange. (I.2.397-402)

Both Pointon and, to a lesser extent, B.J. Sokol have noted that pearls were associated with healing and protecting the body. As Albertus Magnus explains, pearls "relieve difficulty in breathing and heart attacks and fainting fits" (I06). During the Renaissance, pearls, supposedly born in oysters from "divine dew" or tears of the gods, became a symbol for the Virgin Mary's Immaculate Conception or for the immortal soul housed in an earthly body. Alonso's pearl eyes are reminiscent of Matthew 13.45-46, when Christ compares the kingdom of heaven with a merchant seeking pearls who sells everything to buy the most valuable pearl he can find. Pointon records a number of reported instances when pearls prolonged life, prevented fainting, and, as Samuel Gardiner declared in 1609, remedied "panting of the heart" (qtd. in Pointon 108). Although Sokol, drawing from a number of early modern medical texts that state that pearls resulted from an infection in the shellfish, argues primarily for a negative reading of pearls as a "hardening or affective encasing" (46) of the self, he maintains that Alonso ultimately experiences spiritual renewal after undergoing a sea-change. Coral and pearl, then, were rich treasures that protected the human body from decomposition. Whether Ariel's second song brought to mind the Medusa's head or the crucifixion, coral's natural history tells the tale of "a force of destruction [that] is transformed, seemingly miraculously, into a beautiful and vivid part of the natural universe" (Pointon 137).

\section{Environments That Resist Decay: Coral in the Sea Grotto}

Early modern writers included coral within a larger set of natural phenomena that exhibited an extraordinary, complex taxonomy: amber, seashells, travertine, pumice, stalactites, fossil, and pearl. Think of the shepherd's promise to give the nymph a straw belt with "coral clasps and amber studs" (I126) in Christopher Marlowe's poem, or King James's grotto aviary embellished with "snails, mussels, mother-of-pearl and all kinds of curious sea plants"; in these polytemporal objects, or "untimely matter"—to borrow a 
term from Jonathan Gil Harris-a significant presence from the past endures that destabilizes the present. ${ }^{8}$ Rather than exclude untimely organic material from the horticultural domain of the English garden, John Evelyn, an avid collector and a founding member of the Royal Society in 1660 , located marine zoophytes and lithophytes in the grotesque (from It. grotta: "cave") spaces of the sea grotto, a geographic hybrid space combining intertidal zone, seashore, and seafloor. In "Chapter X. Of Rocks, Grots, Crypta's" of Elysium Britannicum, Evelyn both builds and decorates with coral, which he clearly finds fascinating and vibrant:

The Chiefe materials to be used applicable\} on these Workes [the sea grotto] are the hard hony-comb millstone, Sea Rock, Talkes of all Colours, Coarse Coralls, black, white, red, petrified Issickles of which there is sort in Ireland which is yellow $\&$ transparent like Amber . . . afterwards [the surface is to be] inriched with Conchiliage, Corrall, Flags, Sedge, Ivy and other accidents frequently adhearing to them, such as are the Spongg Stone, the pumex, all sorts of Conchae Laevigatoriae brought out of Turkie and Egypt: The Umbilicus or Sea beane which are of sundry unfractuous forms, $\&$ beautifully spotted. (I89)

Elysium Britannicum, a cutting-edge gardening and engineering manual with instructions for planting, sketches of hydraulic technology, and traditional natural philosophy, is considered a key resource in the field of Renaissance ecocriticism precisely because of the wealth of information revealed in passages like the one above. As Evelyn describes how to cultivate an untouched natural landscape ironically by joining geographically remote plants and minerals, it becomes increasingly apparent that the sea grotto is an artificial recreation of a landscape that does not exist. As he designs this space, he moves quickly from an aesthetic justification for choosing particular shells ("beautifully spotted") to one based on naturalist reasoning (the need to retain "accidents" adhering to stones), and he collects widely, from English colonies (Ireland), England, and parts of the Ottoman Empire. Because a garden sea grotto requires so great a quantity of coral, Evelyn prudently offers extremely detailed instructions for two coral simulacra-one made from the "extravagant branches of the white-thorne," dried and plunged in hard wax, and another composed from the "shavings of \{goates\} hornes" steeped in lye and "Ashwood ashes 15 days together" (190), and dyed vermillion. "Petrified branches," "faire 
Mother of Pearle," prodigious quantity of shells, coarse amethyst and crystal, scallop or "Pilgrims shell" from the shores of Malta, oysters, and sponge stone (pumice) "out of Turkie and Egypt" in all their seemingly wide, global variety belong together inside this British sea grotto- “indeede," Evelyn explains, you may use "whatsoever is irregular and best resists the continuall tricklings, \& cadence of waters, $\&$ penetration of Frosts" (I89). Because they contain the memory of a past life-stalactites, or "Issicles," form as water seeps through lime stone, sea creatures emit their shells and then discard them, travertine rock forms near hot springs, pumice is cooled volcanic lava, fossils retain an animal or plant imprint, etc.- the combined effect creates the illusion of geological ancientness in a gentleman's garden far surpassing a human life span. This aesthetic, as George Hersey writes, "juxtapose[ed] ruins . . a against a Nature that was superabundant and volatile, fertile and dangerous" (63).

Undead, organic material involved in the production of Evelyn's sea grotto visually disrupts classical landscape design and suggests that, as Luke Morgan reminds us, "Renaissance gardens are places of pleasure and peril" (176). Morgan cautions us to balance our tendency to valorize the "sanitized Arcadia" with early modernity's many contradictions and ambivalences regarding nature, including the period's tendency to acknowledge "violence, debasement and death" (172) inside a pleasure garden. Traditional landscape architecture does seek to recreate "ideally ordered nature," since "trees were planted in rows and compartments, as were the herbs and flowers, the whole composed of regular geometric units" (Lazzaro 45). But on the other hand, early modern landscape design could exemplify disorder or incongruity. For example, Morgan finds evidence of Mikhail Bakhtin's grotesque in Ovidian motifs and statuary (of which there are many Renaissance examples, including Bomarzo's "Hell Mouth") and extreme landscape design such as twisting labyrinths, colossal mounts, tree houses, subterranean passages, and the sea grotto. The grotesque, as Bakhtin explains,

ignores the impenetrable surface that closes and limits the body as a separate and completed phenomenon. The grotesque image displays not only the outward but also the inner features of the body: blood, bowels, heart and other organs. (318)

Certain species, including coral, fit Russo and Morgan's description of the grotesque. Besides the sexual violence suggested by its Ovidian etiology, a branch 
of coral resembles the body's arteries presented naked, stripped of flesh, while a coral colony multiples our perception of bodily excrescences and orifices. More than orangeries, pergolas, or animal menageries, the uplifting and exposure of the anatomy of the sea in these grottos, often quarried within artificial mounts built for this purpose, creates a defining architectural break from the medieval past and prefigures Mannerist gardening innovations. Such structures materialize widespread admiration, praise, and fear of the ocean's exquisite otherness, particularly when compared to creatures found on land. Izaak Walton cites the "Prophet David," who writes, "They that occupy themselves in deep waters see the wonderful works of God," but then exceeds David's praise of the sea, calling it a space containing "such wonders and pleasures too as the land affords not" (48).

As early as 1979, garden historians began to notice creative similarities between Shakespeare's last play and the influx of Italian gardening renovations in Jacobean England, including those found in Sir Robert Cecil's garden at Hatfield Hall, which were built to entertain the king during his progress in July I6II, and Queen Anne's Parnassus grotto (1609) at Somerset House. In his hallmark survey of "late Mannerist garden marvels" (IO3) in England, Roy Strong mentions The Tempest (likely composed in 1610, but performed at Blackfriars and at court in I6II and I6I3) and "its magical island, its monsters and strange happenings" (103):

The Tempest is also a Mannerist fantasy in the visual sense. Its figures and phenomena are just such as could be found in the royal gardens in the years when the play was written: water nymphs, the monstrous Caliban ('A man or a fish ... like fish his arms'), the 'strange shapes,' simulated thunder and lightning, vanishing tables and spirits in the shape of dogs and hounds. We seem, in fact, at times, to be wandering through a garden by [Saloman] de Caus where we are suddenly confronted by dreamlike monsters, or entering a wild grotto to be struck suddenly, at the turn of a stopcock, with surprise and wonder at moving statues and magical music, as gods and goddesses spring to life and enact an intermezzo. (IO3)

Strong was right to compare The Tempest with an Italian garden: automata crept from rustic caverns at Pratolino, Tivoli's hydraulic organ played autonomously, Evelyn observed thunder, wind, and rain mimic a tempest at the Villa Aldobrandini at Frascati in 1644, and ludic jets of water ("giochi d'acqua") 
sprinkled visitors at nearly every garden. The water jets at Castello's grotto drenched its visitors so completely that contemporary literature often compared the experience to a "sudden attack of enemy soldiers emerging from secret hideouts" (Tchikine 63).

Although the English Civil War prevented a complete Italian landscape renovation, Inigo Jones and Samuel Daniel's investiture masque Tethys, Queen of Nymphs and Rivers stands out in particular as a possible inspiration for Shakespeare's theatrical use of the sea grotto aesthetic, as does the investiture sea-pageant on the Thames, described in a pamphlet published in the same year by Anthony Munday. Upon completion of the sea pageant, the London Corporation rewarded two of the King's Men, Richard Burbage and John Rice, for their performances by allowing them to keep their costumes-an adult-size Amphion costume, presumably used for Caliban, and a boy-sized Corinea costume, presumably used for Ariel as-the-sea-nymph. Gabriel Egan suggests that these two sea-pageant costumes "shaped the characters of Ariel and Caliban" (165). Although the sea pageant celebrates Prince Henry's ability to calm the waves, Shakespeare's play manifests a more critical view of Prospero's false tempest and the theater's power of deception. While we have no proof that Shakespeare's company obtained a Tethys costume, I agree with Egan that the "most knowing of The Tempest's original audience" (162) may have seen both the sea pageant and Daniel's masque. If so, these privileged spectators would surely have associated Tethys's gorgonesque, coral-branching crown with Ariel's song.

Written to celebrate Henry Stuart's investiture as Prince of Wales and to inaugurate Queen Anne's new Italian garden at her principal residence, Somerset House, the masque was presented at Whitehall on 5 June 1610. The queen was cast as Tethys, wife of Neptune, and Princess Elizabeth represented the Thames, one of thirteen attendant river nymphs. The costumes and set, designed by Jones, complemented Daniel's choice of theme: the queen sat in a jeweled, silver scallop (a "great Aquatick throne") supported by sea horses, and her ladies appeared in four rustic caverns ("more rocke, and Cavern-like varying from that of Tethys throne") supported by nonhuman creatures (whales, dolphins, and seahorses) and draped with seaweed garlands. ${ }^{9}$ As Dan Brayton observes, dolphins were considered "monarchs of the Deep" (Shakespeare's Ocean II6) who attended on Neptune himself and resembled humans in their capacity for friendship and love of offspring, while whales were both feared and honored in memory of the biblical leviathan. Other stage scenery included "maske-heads, spouting water, swannes, sestons of maritime weedes, great 
shels, and such like" that mingled rusticity with gold and silver to create the sense of contrast valued so highly in the period's gardens. Their dresses, silver cloth embroidered with gold, featured skirts "wrought with lace, waved round about like a River, and on the bankes sedge and Sea-weedes, all of gold." "Their head-tire," Daniel writes, "was composed of shels and corrall." The women emerge from niches and move to "decke Apollos Tree, / The tree of victory" (3I9) with flowers in golden urns, perform three dances, and then return in their normal forms to affirm their devotion to James and Henry.

Tethys introduces a number of conflicts that Shakespeare explores in The Tempest: the problematic absence of custodial work to be done in the sea grotto; the early Stuart masque's tendency to overstate its sovereignty of the ocean (James as Neptune, the "Ocean King"); the unsettling role of women in patrilineal succession, which Shakespeare dissolves by erasing mothers-including Medea, whose speech Prospero appropriates in act 4-from The Tempest; and the collocation of fertility emblems and signs of imminent danger, such as the leviathan. The coral headpiece challenges an "entirely terrestrial human ontology" and evokes Medusa's petrifying gaze, but it intensifies the queen's otherness in racial-geographic terms as well since coral connotes North African waters and the masque's thirteen rivers are English..$^{10}$ The masque has the effect of distancing the queen from her son, particularly when her speech to him contains conflicting advice. Henry ought to reject "Alcides pillars," or the Strait of Gibraltar, and the colonial treasure brought from "Indies to Iberus"these phrases urge Prince Henry to confine his imperial ambition. Tethys gives him Astrea's sword but it must be sheathed, as the British Isles will be "world enough" to yield him glory. Within the "watery Government" of the sea, however, are "certaine riches" since "Nereus will by industry unfold / a Chimicke secret, and turn fish to gold" (315). Anne's speech exhorts her son (and the audience) to support the crown's project to institutionalize the realm's scientific and artisanal work in order to achieve Francis Bacon's scientific utopia: after all, what more profitable, abundant form of marine life existed for the East India Company than coral, which could be traded for diamonds?

In The Tempest, Shakespeare recycles Jones's crown of "shels and corrall," designed for Neptune's wife, in order to create his poetic vision of Alonso's non-decomposed coral and pearl corpse. Queen Anne's crown becomes King Alonso's bones. Although the underwater sovereigns in Tethys and The Tempest eventually return to land, the corpse in Ariel's song invites an unflattering comparison between man and marine zoophyte: even a sovereign appears weak 
and vulnerable compared to coral or pearl, which flourish on land or sea, share apotropaic properties, persist in living, and increase in material value and beauty after ostensibly dying. Unlike the masque's decorative use of coral, Ariel's song exposes "humanity's underprovisioning in the face of the environment" in what Laurie Shannon describes as man's "negative exceptionalism" (176), or lack of self-sufficiency and radical dependency on the nonhuman. The Boatswain comprehends the terrestrial limits of Alonso's decidedly contingent form of sovereignty in the play's opening scene, as he asks, "What cares these roarers / for the name of the king?" (I.I.16-I7). Alonso could no less command the weather than extend his dominion over the water, a space that Dutch jurist Hugo Grotius defines as a universal commons: "the sea is common to all, because it is so limitless that it cannot become a possession of any one, and because it is adapted for the use of all, whether we consider it from the point of view of navigation or of fisheries" (qtd. in Brayton $180-8 \mathrm{I})^{12}$ Thus coral, as deeply unstable as the sea, presents an ambivalent set of ideas as it pertains to monarchy in Ariel's second song: on one hand, coral's indestructability across land and sea far exceeded that of any individual king, who could not extend his dominion beyond the seashore. But on the other hand, bonding the legal fiction seen in the king's second body with coral's terraqueous nature might spare an individual sovereign; this, I suggest, is how Alonso survives The Tempest.

\section{The King's Coral Body: Preservation and Resurrection}

The Tempest is a particularly important text for ecocritics since Shakespeare experiments with so many standard greenworld genres: Ceres's georgic masque; Ferdinand and Miranda's pastoral romance; Gonzalo's utopian gloss on Montaigne; and the many borrowings from travel narratives and shipwreck tales heavily involve the natural world and reflect central theological and philosophical preoccupations-fate, chance, providence, revenge, and forgiveness. Within ecocriticism, however, there is new momentum to appreciate the sea itself. According to Mentz, who produced one of the first full-length studies of oceanic Shakespeare, Ariel's song can be read as a "metaphor for the artistic process, or theatrical magic, or mutability itself," but one risks losing the "real taste of the ocean" (r). For Brayton, Shakespeare used the sea as a symbol for "figuratively sounding a seemingly measureless and ungovernable entity" such as the imagination's depths, poetry's meaning, or human interiority ("Sounding the Deep" I). Because Prospero commands the weather and exploits both 
Ariel and Caliban for their knowledge about the island's climate and natural resources, William Boelhower argues that the island is a "weather theater" or "fitting laboratory for ... meteorological experiments" to terrorize its inhabitants (3I). Egan is similarly critical of Prospero, whose primary activity on the island is deforestation and the "axeing of trees" (155), reminiscent of colonization in Ireland. Todd A. Borlik points to the deforestation that was a problem for the Irish and for residents of the Lincolnshire fens, who were dispossessed of their land by Jacobean aristocrats. Still, few studies other than Brayton's most recent work look carefully at particular forms of sea life in The Tempest.

In Richard II, England is a "sea-wallèd garden" (3.4.43) and a "precious stone set in a silver sea" (2.1.46), but the uninhabited island of The Tempest is a sea-walled grotto-mussels, barnacle geese, crabs, pearl, and coral join ocean waves, rocks, "the ooze / of the salt deep" (I.2,252-53), mud, mantled pools, and fresh springs to create an organic space on the margins of civilization where the co-conspirators' sinful past does not decay, dissolve, or die. The difference between these two spaces-garden and sea grotto or seashore-is significant. On one hand, a garden calls to mind the biblical tale of Eden, man's disobedience, and Adam's curse in Genesis 3.17-19: "cursed is the ground for thy sake: in sorow shalt thou eate of it all dayes of thy lyfe. Thornes also and thistles shall it bring forth to thee: and thou shalt eate the herbe of the field. In the sweate of thy face shalt thou eate bread" (Holy Bible). Postlapsarian Earth needs stewardship, and Shakespeare's many gardening analogies respond to that need by emphasizing the possibility that a community might redeem Adam's curse through shared physical labor. Very often the comedies and histories embrace a georgic ethic of improvement aimed at the body politic: examples include Scroop's prediction that Henry will "weed the land" (2 Henry IV 4.1.205) of traitors, Vincentio's complaint that Angelo "weeds" (Measure for Measure 3.2.258) another's vice but not his own, or Jacques's command in As You Like It that Duke Senior "weed your better judgments / of all opinion that grows rank in them" (2.7.45-46). The two most important rhetorical topoi for the Virginia Company's publicity campaign in 1613 , as John Gillies observes, were fruitfulness and temperance, each of which requires an industrious colony to cultivate a "moralized landscape" ("Shakespeare's Virginian Masque" 220). On the other hand, a sea grotto or seashore - and its fossilized contents - are immune to decomposition. Evelyn specifically selects self-sustaining material that "best resists the continuall tricklings, $\&$ cadence of waters, $\&$ penetration of Frosts" (I89), which Lazarro describes as calcified deposits: limestone encrustations, 
petrified materials, or porous rock embellished with mother-of-pearl, coral, and seashells such as "limpet, conch, cockle, murex, sea ear, mussel, oyster, scallop, and clam" (6I). It is not just an enchanted island that allows Prospero and Miranda to survive their exile-it is a coastal setting suspended in time where organic material neither grows nor erodes.

Reminders from the past constitute the present for the post-metamorphosed fauna of the sea grotto, and a similar temporal pattern obtains for the play's central characters as well. Ariel must be told to remember his debt to Prospero, who cannot forget Alonso and Antonio's twelve-year trespass; Miranda remembers her attending ladies from the "dark backward and abysm of time" (1.2.50), and she must listen to and remember her father's imperative commands regarding her love for Ferdinand; Caliban, who reminds Prospero that "this island's [his] by Sycorax [his] mother" (1.2.33I), is told to remember that he attempted to violate Miranda, an event that, as Patricia Seed argues, Prospero "opportunistically uses ... as a pretext to seize the island" (2II); and Prospero must acknowledge his linguistic bonds with Ariel, Caliban, and the co-conspirators, whose "penitent" (5.I.28) change is a sign that he must release them. To further signal memory's importance, Prospero forgets Caliban, Trinculo, and Stephano, who plot to kill him during Ceres's masque. When Shakespeare adapts Montaigne in Gonzalo's wish to "have plantation of this isle" (2.1.143), he quickly reminds the audience that any European will bring sinincluding sins as grievous as an attempt at regicide-into the New World's Golden Age. As Evelyn Tribble writes, it is the "crisis of forgetting" that agitates Prospero in act 4 and ultimately "link[s] the collapse and dissolution of the masque to the larger dissolution of the 'great globe' and to mortality itself" (16I). Clearly history is crucial to the text, as it is for coral, pearl, and the other fossilized life forms gathered in the sea grotto, each of which draws its idiosyncratic power to heal and protect the human body from a Western tradition, going back to the ancients, that gave these entities an indeterminate position in the web of life.

While Ariel's second song has attracted attention for aesthetic reasons, the biological indeterminacy of Alonso's coral and pearl corpse is usually overshadowed by an interest in Caliban's creaturely status. As critics such as Brayton have noted, the text immediately underscores Caliban's ambivalent taxonomic position as an "islander" (2.2.35): Caliban is a "strange beast" (2.2.30), "legged like a man" but with "fins like arms" (2.2.32-33), a "monster of the isle with four legs" (2.2.64), and "half a fish and half a monster" (3.2.29) who is 
"litter[ed]" as a "freckled whelp" (1.2.282-83) by Sycorax, his mother. To Brayton, Caliban is "etymologically, culturally, and ontologically both maritime and wild.... a fraught embodiment of the sea's strangeness" "Shakespeare and the Global Ocean" 185), while Simon Estok somewhat problematically suggests that Caliban is simply "part of the exotica that defines the landscape of the imperialist gaze" (104). But the image of Alonso's coral body, equally strange, functions very differently since this specific marine species was so admired. I want to suggest that Alonso's imagined transformation into a plant-stone corresponds to a complex set of issues including the redemption of the king, who must "become a repentant, loving man" (Hansen 216) and learn to see better. Alonso's dehumanization-although equivocal in some respects-produces the opposite effect of Caliban's fraught taxonomy by elevating Alonso: the coral motif preserves the crown by framing a state of nature in a way that supports the fiction necessary for the theory of a two-bodied king. In addition, the global trade in coral unites the play's disparate geographic locales as efficiently as any other contemporary practice, including piracy: coral fishermen traveled from the Gulf of Naples (Alonso's realm) and harvested coral in the Mediterranean near the North African coasts of Tunis (where Claribel is queen) and Algiers (Sycorax's homeland).

When Alonso's skeleton becomes coral, these changes in its physiological structure create a provocative metaphor for the body politic. Entitled from birth, a sovereign exists in a separate category from that of the average human as a result of the legal fiction attached to kingship and developed by Elizabethan jurists to protect crown land. This legal fiction required that the mortal and material "body natural" of a king perfectly converge with his second body, the immortal and immaterial "body politic." According to crown lawyers, the king's body politic was "utterly void of Infancy, and old Age, and other natural Defects and Imbecilities, which the Body natural is subject to" and was thus always alive and capable of legal ownership. ${ }^{13}$ Every king had two bodies, and, in theory, the supposed transferral of this metaphysical body from one natural body to the next was meant to signify a legitimate and uninterrupted succession from one sovereign to the next. In one capacity, then, Alonso is utterly alien to the material world at Naples: as a half-transcendent being who embodies the mystical body politic, he cannot die, he cannot err, and he cannot be subject to Aristotelian accident. Alonso's coral skeleton, an apt metaphor for the body politic, will never fade, diminish, or decay in any context; coral's seemingly infinite capacity for skeletal endurance contrasts with the vulnerability of 
the human body. In fact, the most vulnerable humans, infants and children, were frequently given coral teething rings, as seen in the anonymous 1630 portrait of the infant Charles II that displays the baby wearing a red coral teething ring attached to a diamond chain (fig. 3).

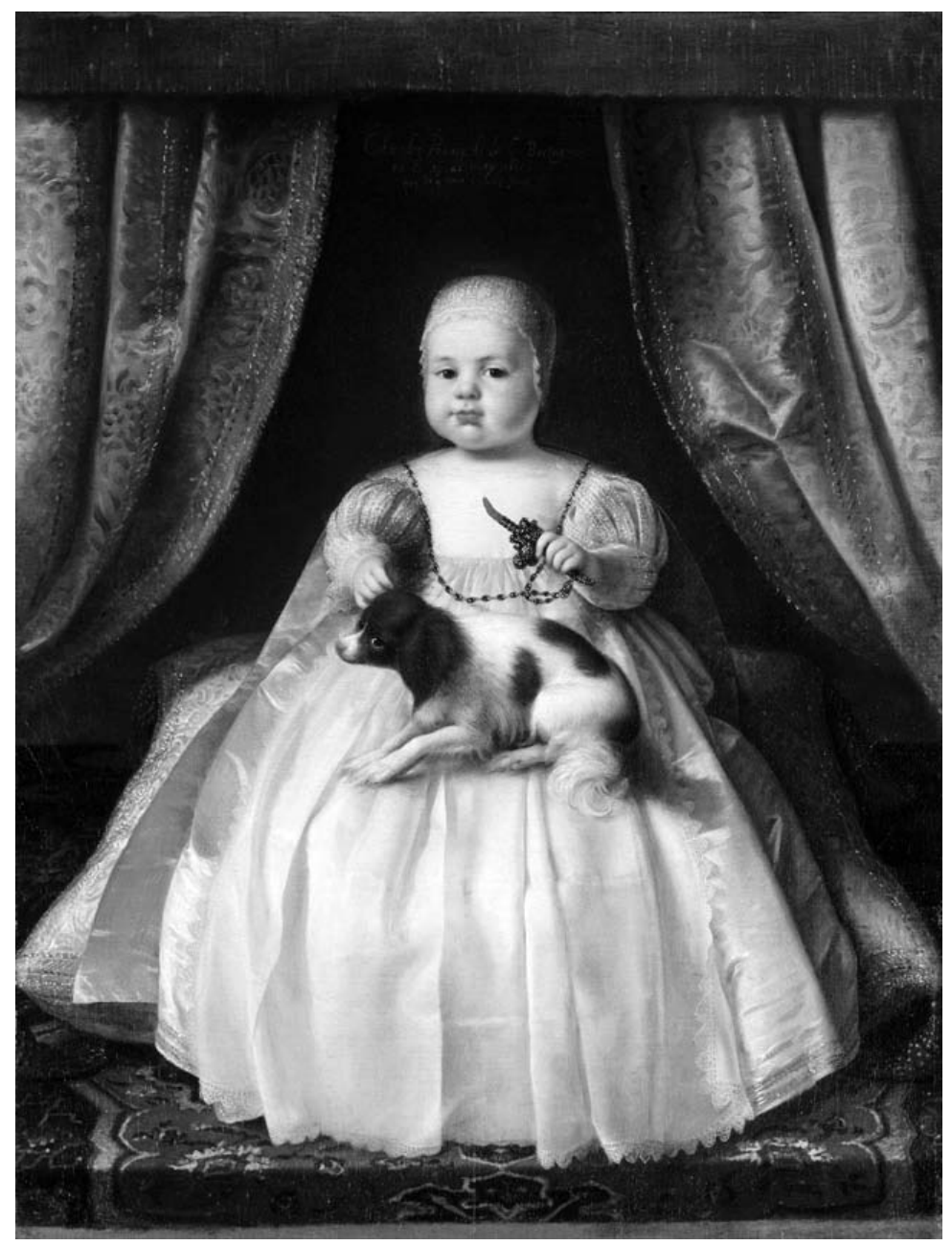

Fig. 3: "Charles II of England as Prince of Wales" (1630). Unknown Artist. London: National Portrait Gallery. 
Events in The Tempest threaten Alonso's private body in two ways: Antonio and Sebastian conspire and attempt to assassinate him, which I will discuss first; and a sense of grief so overwhelms Alonso that he nearly tries to drown twice. The sea grotto's unique collocation of seafloor, which often signifies despair, and seashore, a site of destiny and hope, disarms each threat, while his association with coral and pearl link him to notions of survival through transformation and self-preservation. This sort of preservation takes place when Ariel intervenes to interrupt the attempted regicide: "My master through his art foresees the danger / that you, his friend, are in, and sends me forth" (2.1.296-97). Although the "friend" to whom Ariel directs these lines could be either Gonzalo or Alonso, Prospero acknowledges Gonzalo's charity throughout the play and embraces him as a "noble friend" (5.I.I20) in act 5, while he initially recalls that Alonso is an "enemy ... inveterate" in act I (I.2.12I-22). Still, the more proper sphere of friendship for a sovereign is a man of equal rank, and thus the post-tragic relationship that properly showcases forgiveness and future amity is the reconciliation of Alonso and Prospero. For Gillies, these men are "creatures whose potential is perpetually cancelled by their history" ("The Figure" 180), but, in fact, at least Alonso must acknowledge his sinful past before Prospero will forgive him and release the island's prisoners. It is the grotto's preservation of this history within memory that ironically leads toward a recovery in the private lives of kings and in their corporate personalities.

The Tempest encourages us to find similarities between Alonso and Prospero, neither of whom was an ideal prince: Prospero misgoverns Milan, allowing a private interest in the occult to supersede public office, while Alonso, distracted by private grief and his own participation in a usurpation, invites rebellion. Yet these political rivals evolve when they are far from civilization and stranded in the coastal zone, either "exposed unto the sea" (3.3.7I) or "belch[ed]" up by the "never-surfeited sea" (3.3.55-56). Prospero disavows his occult books, but, equally importantly, chooses to forgive. As Beckwith argues, Prospero may release the co-conspirators from their distracted trance only when he is released from his equally constraining vengeance plot: "this release for Prospero," as Beckwith notes, "will involve learning to accept his humanity, becoming kind, inhabiting his kind" (I49). Prospero's "humanity," defined as that which requires acknowledgement and self-reflection, leads to an emergent friendship with Alonso, the restitution of his kingdom, and the chance to resurrect his own coral body, signified in the ducal attire with which he greets the co-conspirators. Therefore, Prospero earns the chance to be supra-human again; that is, he inhabits the indestructible body that accompanies sovereignty. 
The second way that events in The Tempest threaten Alonso is through selfdespair. Alonso twice wishes to die in a way that would enact an elemental sea change and test the limits of the sovereign body's indestructability: in act 3, he notes 'my son i' th' ooze is bedded; and / I'll seek him deeper than e'er plummet sounded, / and with him there lie mudded" (3.3.100-02); and in act 5, he "wish[es] / myself were mudded in that oozy bed / where my son lies" (5.1.15052). Such desire is even more unusual given the Elizabethan fear of death at sea, as seen in Clarence's horrific dream in Richard III of "a thousand fearful wrackes, / a thousand men that fishes gnawed upon" (I.4.24-25) in an undersea graveyard, the "slimy bottom of the deep" (I.4.32). Sokol has argued that Alonso seeks this unusually terrifying form of death to escape two burdens other than his present shipwreck - twelve years of guilt over his "trespass" toward Prospero and Ferdinand's more recent death. For Sokol, the "mineral transformation" of the king's eyes in Ariel's song stems from Alonso's "longstanding disease of 'disowning knowledge" (45), the problem that Stanley Cavell identifies as the root of tragedy. According to Sokol, pearl eyes blind Alonso to the truth, repress his guilt, harden his heart, and signify the defense mechanisms of twelve years of "habitual mental evasions and hypocrisies" (46).

But Alonso's suicide ideation - to lie "mudded" or "bedded ... i' th' ooze" has a zoophytical resonance that again could be explained through his association with coral reefs. To "mud" (def. v. I) has a number of valences: to make obscure, or to tarnish; to catch fish by clouding water with sediment from the seabed; and to be buried in mud, the definition that the Oxford English Dictionary associates with Alonso. But to "mud" also pertains to "fish or other aquatic animals" when they "lie dormant, burrow, or hide in the mud" (def. $3 \mathrm{v} . \mathrm{I})$. This last, more positive definition opens up a number of possible explanations for Alonso's unique picture of despair. If coral is a zoophyte with a skeletal component that becomes an indestructible mineral, Shakespeare implies that Alonso is just as fish-like (or, as Brayton suggests, crab-like) as Caliban, for he could lie dormant safely on the seafloor. Although this image does not preclude the notion of someone who needs to hide, it does reaffirm the salutary nature of Alonso's retreat to passion and despair: coral's amphibious capacity as a terrestrial and aquatic life form protects Alonso until it is the right time for him to be seen by Prospero. When Alonso's vaguely ominous punishment to live the remainder of his days on the island in "lingering perdition, worse than any death" (3.3.77) never happens (since Prospero chooses forgiveness over vengeance), it becomes clear that when the sovereign's family tree is coral, Prospero cannot cut its branches. 
Finally, it must be acknowledged that coral has obvious limitations: in no early modern account does a writer suggest that coral thinks, speaks, or ascends to heaven. Even so, coral possesses supra-human qualities: it survives radical upheaval, becomes reborn as a mineral, and then proceeds to command rain, tempest, whirlwind, bodily illness, and the fiends of hell, while protecting children and the dead. And in The Tempest at least two of the play's characters (indeed, two of its gentlemen) cease to be men. Fratricidal Sebastian is subvegetal-a standing pool of stagnant, unhealthy water and "hereditary sloth" (2.I.222) - while Antonio's conscience, a key point of distinction between humans and nonhumans and crucial for Christian redemption, is "candied" (2.1.278) or congealed-effectively inoperable. Shakespeare's tragi-comic villains should authentically repent and convert at the comedy's end, but even this mutability undermines an abiding need to recognize constancy over time. This notion is expressed in Gonzalo's wish to record Milan's dynastic restoration and "set it down / with gold on lasting pillars" (5.1.207-08). As a vegetal mineral and as a zoophyte whose genesis incorporates sea foam, air and dew, coral troubles every conceivable taxonomic boundary, yet retains its species and neither decays nor dies. The same simply cannot be said for humans, although from a metatheatrical perspective it could be said for theater itself, where each revival reinvents the skeleton-script of an old play in the new embodiment of a unique production and performance.

It would not be wrong to suggest that Shakespeare wants us to save the coral reefs; the Renaissance enjoyed a widespread love affair with coral. Still, to save the reefs implies that coral lacks agency, and clearly coral resurrects life, protects young children, funds the diamond trade, calms rough weather, and multiplies fruit and vineyards. But the species does not simply save humans: both formulations are too reductive, while the former requires that a modern attitude toward environmental stewardship descend from the beliefs and habits of the early modern period. Yet it is deeply ironic that early moderns celebrated coral's resistance to decay at the same time that their coral-harvesting was depleting the Mediterranean reefs. These reefs were neither perpetual nor invulnerable, despite an early modern faith in the ocean's presumably innate and limitless fecundity. The English crown did manage marine and riparian life during "fence months" (March, April, and May), however, a practice that allows us to glimpse early modern attitudes that prefigure our efforts to create sustainable fisheries. In The Compleat Angler (1653), Walton discusses a statute from the reign of Edward I that states that particular rivers "shall be in defense 
[i.e., prohibited] for taking Salmons from the Nativity of Our Lady unto St. Martin's Day and that likewise young Salmons shall not be taken nor destroyed by nets, nor by other engines, at mill-pools, from the midst of April unto the Nativity of St. John the Baptist." Men who illegally angle for "Fish in Spawning time" violate religious imperative, natural law, and courtesy or custom. "Unnatural men" who do not keep "Fence months" commit a "sin so against nature, that Almighty God hath in the Levitical law made a law against it" (6I). Borlik's distinction between contemplative and consumptive dwelling corresponds roughly to Walton's natural and unnatural man; to be "natural," then, is to dwell among rivers that foster young salmon. In The Tempest, Shakespeare makes an important gesture in Ariel's second song: his coral is not Donne's bracelet ("the corals, which thy wrist enfold," as described in "The Token"), Marlowe's belt clasp, or Jones's crown of "shels and corrall," but the very bones of England's resolutely corporeal metaphor for kingship. Mediterranean coral naturalizes sovereignty as a perpetual force, but it also renders it monstrous, controversial, and grotesque, for coral (of unknown taxonomy and wondrous origins) occupies a space beyond Adam's green dominion. To then view the body politic as a sea-grotto-permeable, open, and exposed to the oceanrather than a garden broadens contemporary understandings of early modern political ecology and reflects England's emergent dependence on transoceanic commerce, which included harvesting the treasures of the sea.

\section{NOT E S}

I. See Shakespeare, The Complete Pelican Shakespeare. All subsequent references to Shakespeare's works are to this edition and are cited parenthetically by act, scene, and line number.

2. There are two recently edited collections, Ecocritical Shakespeare (20II) and Early Modern Ecostudies (2008), in addition to a number of full-length monographs, such as Egan's Green Shakespeare (2006), Mentz's At the Bottom of Shakespeare's Ocean (2009), and Brayton's Shakespeare's Ocean (2012), that develop ecocritical readings of Renaissance texts. Although those five works were particularly influential for this essay, see also Todd Borlik's Ecocriticism and Early Modern English Literature (201I), Ken Hiltner's What Else is Pastoral? (2010), Jeffrey Theis's Writing the Forest (2010), Simon Estok's Ecocriticism and Shakespeare (201I), Robert N. Watson's Back to Nature (2006), and Sylvia Bowerbank's Speaking for Nature (2004). Brayton's Shakespeare's Ocean (20I2) was published just as I completed this article.

3. See Pliny 32: II.

4. Coral's affinities with contemporary posthumanist discourse exemplify how ecocriticism is deeply indebted to science studies, a field that includes history of science, philosophy of science, and sociology of science. For those who study early modernity, sociologist Bruno Latour's We Have Never Been Modern (1993) has been particularly influential because it argues that the objective analysis of fact in techno-scientific institutions does 
not function due to a strict separation of subject and object or man and nature. Rather, scientific knowledge is constructed (historically situated and contingent on practitioners, politics, economic interests, etc.) just as any other temporarily stable form of knowledge. For a strong explanation of constructivist thought, see Smith.

5. Although I have not found examples of a robust transatlantic coral trade (other than two or three instances from Richard Hakluyt's Principle Navigations), see Las Casas 93-94 for the lethal working conditions of natives who were forced by the Spanish to dive for pearls from 1508 until the 1520 . Initially an operation that began in the Bahamas, Las Casas claims that its intense labor decimated the population: "the pearl fisheries have been the grave of countless non-Bahamians also, drafted in from other parts of the New World" (94). For a comprehensive history of the pearl industry in New Spain, see Donkin.

6. "Demonibus est terribilis et hoc forte quia frequenter formam cruces habet ramorum eius distencio" (qtd. in Evans 227).

7. See Pointon II4.

8. The description of King James's grotto aviary is that of Johann Wilhelm Neumayr von Ramssla, the German escort of the Duke of Saxony, both of whom toured England in 1613. Neumayr included his account of early Stuart gardens in Des Durchlauchtigen hochgebornen Fursten, published in Leipzig in 1620. Qtd. in Strong 96.

9. All descriptions of the masque in this paragraph are from Daniel 317-I8.

Io. See Brayton 178.

II. For more on the attempted crown consolidation of the products of techne, see Solomon, who discusses the practice of "monarchical mercantilism," and Picciotto, who introduces the concept of the "working sovereign" by elevating intellectual labor and ingenuity, or handiness.

12. For a detailed description of Early Stuart changes to maritime policy, see Fulton chapters 4-5.

13. Edmund Plowden, Commentaries or Reports (London: n.p., i816), qtd. in Kantorowicz 7 .

WORKS C I T E D

Albertus Magnus. Book of Minerals. Trans. Dorothy Wyckoff. Oxford: Clarendon, 1967. Aristotle. de Partibus Animalium. Trans. William Ogle. London: Kegan Paul, 1882. Google Books. Web. 6 August 2012.

Bachelard, Gaston. The Poetics of Space. Trans. Maria Jolas. Boston: Beacon, 1969.

Bakhtin, Mikhail. Rabelais and His World. Cambridge: MIT P, 1968.

Beckwith, Sarah. Shakespeare and the Grammar of Forgiveness. Ithaca: Cornell UP, 2011.

Boelhower, William. "Owning the Weather: Reading The Tempest After Hurricane Katrina." Borrowers and Lenders 5 (2010): n. pag. Web.

Borlik, Todd. Ecocriticism and Early Modern English Literature. New York: Routledge, 20II. Borneman, Eric H. Aquarium Corals: Selection, Husbandry, and Natural History. New Jersey: TFH, 200I.

Brayton, Dan. "Shakespeare and the Global Ocean." Ecocritical Shakespeare. Ed. Lynne Bruckner and Dan Brayton. Surrey: Ashgate, 2011. 173-90.

- Shakespeare's Ocean: An Ecocritical Exploration. Charlottesville: U of Virginia P, 2012

. "Sounding the Deep: Shakespeare and the Sea Revisited." Forum for Modern Language Studies 46.2 (2010): 188-206. 
Bruckner, Lynne, and Dan Brayton, eds. Ecocritical Shakespeare. Surrey, England: Ashgate, 20 II.

Bushnell, Rebecca. Green Desire: Imagining Early Modern English Gardens. Ithaca: Cornell UP, 2003.

"Coral." Def. n.I. The Oxford English Dictionary. Oxford: Oxford UP. 5 December 2011. Web.

Daniel, Samuel. The Complete Works in Verse and Prose of Samuel Daniel. Ed. Alexander B. Grosart. Vol. 3. London, 1885. Google Books. Web. 5 December 2011.

de Glanville, Bartholomew. De Proprietatibus Rerum. Trans. John Trevisa. London, 1495.

Donkin, R.A. Beyond Price: Pearls and Pearl-Fishing: Origins to the Age of Discovery. Philadelphia: American Philosophical Society, 1998.

Egan, Gabriel. Green Shakespeare: From Ecopolitics to Ecocriticism. London: Routledge, 2006.

Ellis, John. Natural History of Many Curious and Uncommon Zoophytes. London, 1786. Biodiversity Heritage Library. 5 December 201r. Web.

English Medieval Lapidaries. London: Oxford UP, 1933.

Evans, Joan. Magical Jewels of the Middle Ages and Renaissance Particularly in England. Ann Arbor: U of Michigan P, 1922.

Evelyn, John. Elysium Britannicum, Ed. John E. Ingram. Philadelphia: U of Pennsylvania P, 200I.

Fulton, Thomas Wemyss. Sovereignty of the Sea. Edinburgh: William Blackwood, rin.

Gil Harris, Jonathan. Untimely Matter in the Time of Shakespeare. Philadelphia: U of Pennsylvania $\mathrm{P}, 2008$.

Gillies, John. "The Figure of the New World in The Tempest." "The Tempest" and its Travels. Ed. Peter Hulme and William H. Sherman. London: Reaktion, 2006.

- "Shakespeare's Virginian Masque." The Tempest. Norton Critical Edition. Ed. Peter Hulme and William H. Sherman. New York: Norton, 2004. 215-32.

Hallock, Thomas, Ivo Kamps, and Karen Raber, eds. Early Modern Eco-Studies: From the Florentine Codex to Shakespeare. New York: Palgrave Macmillan, 2008.

Hansen, Abby Jane Dubman. "Shakespeare and the Lore of Precious Stones." College Literature 4 (1977): 210-19.

Hersey, George. "Water-Works and Water-Play in Renaissance Naples." Fons Sapientiae: Renaissance Garden Fountains. Ed. Elisabeth B. MacDougall. Washington: Dumbarton Oaks, 1978. 6I-83.

The Holy Bible: King James Version, 1611 edition. Facsim. ed. Peabody: Hendrickson, 2005.

Kantorowicz, Ernst H. The King's Two Bodies: A Study in Mediaeval Political Theology. Princeton: Princeton UP, 1957 .

Krishna, Bal. Commercial Relations Between India and England 1601-1757. London: George Routledge, 1924 .

Las Casas, Bartolome de. A Short Account of the Destruction of the Indies. London: Penguin, 1992.

Lazzaro, Claudia. The Italian Renaissance Garden. New Haven: Yale UP, 1990.

Linnaeus. A General System of Nature Through the Three Grand Kingdoms. Vol. 4. Trans. William Turton. London, 1806. Google Books. Web, 6 August 2012.

Marlowe, Christopher. "The Passionate Shepherd to His Love." The Norton Anthology of English Literature. Ed. Stephen Greenblatt et al. gth ed. Vol. B. New York: W.W. Norton \& Company, 2012. II26.

Mentz, Steve. At the Bottom of Shakespeare's Ocean. New York: Continuum, 2009. 
Morgan, Adam. "The Monster in the Garden: The Grotesque, the Gigantic, and the Monstrous in Renaissance Landscape Design." Studies in the History of Gardens and Designed Landscapes 31.3 (2011): 167-80.

"Mud." Def. v.r. The Oxford English Dictionary. Oxford: Oxford UP. 5 December 2orr. Web. Neill, Michael. "Remembrance and Revenge: Hamlet, Macbeth, and The Tempest." Jonson and Shakespeare. Ed. Ian Donaldson. Atlantic Highlands: Humanities, 1983. 35-56.

Orgel, Stephen. "Prospero's Wife." The Tempest: Norton Critical Edition. Ed. Peter Hulme and William H. Sherman. New York: Norton, 2004. 20I-15.

Ovid. Metamorphoses. Trans. Arthur Golding. Baltimore: Johns Hopkins UP, 200I.

Picciotto, Joanna. Labors of Innocence in Early Modern England. Cambridge: Harvard UP, 2010.

Pliny. Naturalis Historia. Trans. John Bostock. London, 1855. The Perseus Digital Library. Tufts U. 5 December 20II. Web.

Pointon, Marcia. Brilliant Effects: A Cultural History of Gem Stones and Jewellery. New Haven: Yale UP, 2009.

Seed, Patricia. "This Island's Mine': Caliban and Native Sovereignty." "The Tempest" and its Travels. Ed. Peter Hulme and William H. Sherman. London: Reaktion, 2006. 202-II.

Shakespeare, William. The Complete Pelican Shakespeare. Ed. Stephen Orgel and A.R. Braunmuller. New York: Penguin, 2002.

Shannon, Laurie. "Poor, Bare, Forked: Animal Sovereignty, Human Negative Exceptionalism, and the Natural History of King Lear." Shakespeare Quarterly 60.2 (2009): 168-96.

Smith, Barbara Herrnstein. "Netting Truth." PMLA 115.5 (2000): 1089-95.

Sokol, B.J. A Brave New World of Knowledge: Shakespeare's The Tempest and Early Modern Epistemology. Madison: Fairleigh Dickinson UP, 2003.

Solomon, Julie. Objectivity in the Making: Francis Bacon and the Politics of Inquiry. Baltimore: Johns Hopkins UP, 1998.

Strong, Roy. The Renaissance Garden in England. London: Thames and Hudson, 1998.

Tchikine, Anatole. "Giochi d'acqua: Water Effects in Renaissance and Baroque Italy." Studies in the History of Gardens and Designed Landscapes 30.1 (2010): 57-76.

Theis, Jeffrey S. Writing the Forest in Early Modern England: A Sylvan Pastoral Nation. Pittsburgh: Duquesne UP, 2010.

Theophrastus. On Stones. Trans. Earle R. Caley and John F.C. Richards. Columbus: The Ohio State UP, 1956.

Tribble, Evelyn B. "'The Dark Backward and Abysm of Time:' The Tempest and Memory." College Literature 33.I (2006): 151-68.

Trivellato, Francesca. The Familiarity of Strangers: The Sephardic Diaspora, Livorno, and Cross-Cultural Trade in the Early Modern Period. New Haven: Yale UP, 2009.

Walton, Izaak. The Compleat Angler. Ed. John Buxton. Oxford: Oxford UP, 2009.

Watson, Robert N. Back to Nature: The Green and the Real in the Late Renaissance. Philadelphia: U of Pennsylvania P, 2007.

Williams, David. Deformed Discourse: The Function of the Monster in Mediaeval Thought and Literature. Montreal: McGill-Queens UP, 1996.

Yogev, Gedalia. Diamonds and Coral: Anglo-Dutch Jews and Eighteenth-Century Trade. Leicester: Leicester UP, 1978. 